\title{
Szkice
}

\section{POLSKA POSTKOLONIALNOŚĆ W KRZYWYM (?) ZWIERCIADLE PUBLICYSTYKI RAFAŁA ZIEMKIEWICZA}

\author{
TOMASZ NAKONECZNY1 \\ (Uniwersytet im. Adama Mickiewicza w Poznaniu)
}

\begin{abstract}
Słowa kluczowe: Polska, Rafał Ziemkiewicz, inteligencja, folwark szlachecki, nowe społeczeństwo, postkolonializm
\end{abstract}

Keywords: Poland, Rafał Ziemkiewicz, intelligentsia, grange, new society, postcolonialism

\begin{abstract}
Abstrakt: Tomasz Nakoneczny. POLSKA POSTKOLONIALNOŚĆ W KRZYWYM (?) ZWIERCIADLE PUBLICYSTYKI RAFAŁA ZIEMKIEWICZA. „PORÓWNANIA” 16 (2015). T. XVI. S. 165-185. ISSN 1733-165X. Artykuł poświęcony jest zagadnieniu polskiej postkolonialności w ujęciu Rafała Ziemkiewicza, jednego z najbardziej wpływowych polskich pisarzy i publicystów średniego pokolenia. Ziemkiewicz uważa, że struktura społeczna i mentalność współczesnych Polaków, zostały w całości określone przez zmiany, jakie spowodowała II Wojna Światowa i komunizm. Społeczeństwo, jakie się wskutek tych zmian wyłoniło jest tworem historycznie zupełnie nowym. Tym, co łączy je z przeszłością jest jedynie dziedzictwo folwarku pańszczyźnianego i zależności kolonialnej od mocarstw ościennych. Szansę w przezwyciężeniu tego dziedzictwa upatruje Ziemkiewicz w budowie społeczeństwa obywatelskiego, nawiązującego do tradycji pracy organicznej i narodowej demokracji. Ziemkiewicz rezygnuje z charakterystycznego dla polskiej inteligencji oglądu rzeczywistości przez pryzmat ideologii. Znacznie bliższa jest mu tradycja anglosaskiego konserwatyzmu i republikanizmu, oparta na wolności, poszanowaniu tradycji i kompromisie. Autor artykułu próbuje pokazać myśl Ziemkiewicza wolną od stereotypowych zniekształceń, a jednocześnie ukierunkowaną na uwalnianie polskiej tożsamości od brzemienia mentalności kolonialnej.
\end{abstract}

Abstract: Tomasz Nakoneczny. POLISH POSTCOLONIALITY IN A DISTORTING (?) MIRROR THE JOURNALISM OF RAFAŁ ZIEMKIEWICZ. “PORÓWNANIA” 16 (2015). Vol. XVI. P. 165-185.

1. Correspondance Address: dtnakoneczny@wp.pl; dtnakoneczny@o2.pl 
ISSN 1733-165X. The article is devoted to the problem of Polish postcoloniality in terms of Rafał Ziemkiewicz, one of the most influential Polish writers and journalists of the middle generation. Ziemkiewicz believes that the social structure and mentality of contemporary Poles have been entirely determined by the Second World War and communism. The society, which appeared as a result, is something completely new in history. What unites this society with the past is only a heritage of feudal and colonial dependency. Ziemkiewicz believes that the opportunity to overcome this heritage gives reference to the tradition of organic work and national democracy. He resigns from the characteristic of the Polish intelligentsia overview of reality through the prism of ideology. He is much closer to the tradition of the Anglo-Saxon conservatism and republicanism, based on the ideals of freedom, respect for tradition and compromise. The author of the article tries to show the thought of Ziemkiewicz free from stereotypical images and aimed at helping Polish identity to eliminate the colonial mentality.

Byłoby rzeczą wobec odbiorcy w dobrym guście, by nie powiedzieć - elementarnie uczciwą, gdyby autor rozważań nad przedmiotem światopoglądowo wielorakim (czytaj: złożonym i kontrowersyjnym), co w danym przypadku wyraża się jego silnym uwikłaniem $\mathrm{w}$ bieżący spór polityczny, potrafił określić swoje do tegoż przedmiotu i sporu, ni mniej ni więcej, tylko światopoglądowe (polityczne) nastawienie. Odbiorca - zakładam, że byłby to odbiorca modelowo światły, apriorycznie życzliwy i organicznie wyzbyty jakichkolwiek uprzedzeń - wiedziałby wówczas nie tylko jakich pułapek w lekturze może uniknąć (wystarczyłoby mu po prostu wziąć $\mathrm{w}$ nawias wszelkie przejawy autorskiej wyznawczości), ale również to, jaka - i czy w ogóle - wartość poznawcza takim rozważaniom po wydestylowaniu z nich ideowych zniekształceń i subiektywizmów zdolna jest przysługiwać. Wiedząc zaś, mógłby - cały czas przy zachowaniu powyższych założeń - rozpoznać, tak jak mnie się to zdarzyło, pewien wzór myślowy, w który przedmiot ów „światopoglądowo wieloraki" wpisuje się na sposób innych, podobnych, nie tak już kontrowersyjnych, a nawet zupełnie niekiedy standardowych. Co oznaczałoby możliwość spokojnej i rzeczowej oceny tak przedmiotu, jak i okoliczności, w jakich popadł on w niełaskę pewnej grupy ludzi myślących.

Wszelako w odniesieniu do publicystyki Rafała Ziemkiewicza², bo o niej tu mowa, sprawa nie daje się skwitować tak łatwo. I to nie dlatego, bym nie śmiał

\footnotetext{
2 Posługując się, na użytek niniejszych rozważań, terminem „publicystyka Rafała Ziemkiewicza”, dokonuję znacznego zawężenia przedmiotowego. Skupiam się zasadniczo na książkach publicystycznych wydawanych w ciągu ostatnich dziesięciu lat (Polactwo, Michnikowszczyzna. Zapis choroby, Czas wrzeszczacych staruszków, Viagra mać, Myśli nowoczesnego endeka, Jakie piękne samobójstwo), pomijam natomiast, oprócz innych publikacji książkowych, liczne artykuły rozsiane po pismach, z którymi Ziemkiewicz od początku lat 90. współpracował: Najwyższy CZAS, Wprost, Newsweek Polska, Przewod-
} 
wyznać, że do wyrazistych aż do jaskrawości opcji politycznych (skojarzenia autora „Polactwa” z narodowo zorientowaną prawicą, ba, z faszyzmem³, uległy już w pewnych obszarach dyskursu publicznego niejakiej automatyzacji), tak samo jak do ich tekstów fundamentalnych (równie znane jest zadłużenie Ziemkiewicza u wczesnego Dmowskiego, u Balickiego, Popławskiego i innych przedstawicieli przedwojennej endecji), żywię ostrożność wyznawcy zdrowego rozsądku, stroniącego niejako atawistycznie od wszelakiej maści partyjnictwa, sekciarstwa, ideologicznej idolatrii etc. Zresztą, czy Ziemkiewicz - merytorycznie, nie formalnie - na tak jednoznaczne i stronnicze identyfikacje zasługuje, to kwestia na oddzielny wywód, który szkicowo - ze względu na wymogi kompozycyjne niniejszych rozważań - zostanie podjęty.

Podniesiona trudność wiąże się, moim zdaniem, z trzema, co najmniej, okolicznościami, które zostaną pokrótce rozpatrzone. Po pierwsze, z językiem Ziemkiewiczowskiego dyskursu, który dla wielu ideowych oponentów, choć nie tylko dla nich, stanowi przejaw - w najlepszym razie, mowy wysoce "niepoprawnej”, w najgorszym - „mowy nienawiści”, i z tej racji jeśli nie dyskredytuje całości stanowiska autora, to znacznie obniża jego wiarygodność. Po drugie, z diagnozą polskiej rzeczywistości, która czyni naszego publicystę czynnym (niekoniecznie intencjonalnie) uczestnikiem tak zwanej wojny polsko-polskiej ${ }^{4}$ Po trzecie wreszcie,

nik Katolicki, Polityka, Rzeczpospolita, Gazeta Polska, Uważam Rze oraz Do Rzeczy. Za taką decyzją metodologiczną stoi przekonanie, że wymienione książki stanowią najbardziej reprezentatywne, a zarazem najpełniejsze i najdojrzalsze wypowiedzi publicystyczne Ziemkiewicza. Ponadto, i to wzgląd przeważający, świadomie i wszechstronnie podnoszące kwestię polskiej postkolonialności.

3 "Jestem - odpowiada ironicznie swoim adwersarzom Ziemkiewicz - i zawsze byłem faszystą. Zrzucam wreszcie maskę i czynię to z ulgą, dumą i radością, zaprawioną jedynie odrobiną goryczy, że wyznaniem swym sprawiam radość od dawna mnie podejrzewającym zawodowym tropicielom polskiego faszyzmu, licznie przyssanym do rządowych mediów i europejskich grantów". R. Ziemkiewicz, Jak zostatem polskim faszystą. „Do Rzeczy” 2014, nr 13. Na temat faszyzmu w kontekście mowy nienawiści i odwracania pojęć piszą interesująco Ryszard Legutko i Bronisław Wildstein, których refleksje rozwijają wiele wątków obecnych w twórczości publicystycznej Ziemkiewicza. Zob. R. Legutko, Triumf człowieka pospolitego. Poznań 2012; B. Wildstein, Demokracja limitowana, czyli dlaczego nie lubię III RP. Poznań 2014.

4 Polaryzacja polskiej sceny politycznej, „wojna na górze” (między obozami Lecha Wałęsy i Tadeusza Mazowieckiego), kaczyzm i tuskoland, to tylko niektóre z wcieleń narastającej przez lata transformacji wojny polsko-polskiej, utrwalanych $\mathrm{w}$ języku potocznym $\mathrm{w}$ formie nośnych $\mathrm{i}$ automatycznie kojarzonych haseł. Właściwe tej wojnie jest - w odróżnieniu od konfliktów jednowymiarowych, dotyczących np. określonych kwestii socjalnych - pewnego rodzaju duchowe pogłębienie i wysoki stopień emocjonalności, które sprawiają, że nawet najmniej wojowniczy jej uczestnik, skłonny do wypełniania swych żołnierskich obowiązków bez zbędnej wrogości, widzi w przeciwniku nie tyle kontrpartnera (to znaczy kogoś podobnego doń, tylko umieszczonego zrządzeniem losu w przeciwległym okopie), ani też nie tyle - daj Boże - ofiarę jakichś wyższych sił czy racji na modłę bohaterów antycznych, ile Antychrysta wcielającego wizję świata na opak, a mówiąc bardziej akademicko - negatywny i wszystko obejmujący w tej negatywności układ odniesienia. Bo też, na pewnym poziomie metaforycznego zestawienia, jest to wojna totalna, o czym będzie jeszcze mowa. 
występując jako rzecznik słusznej sprawy, demaskator fałszywych postaw, adwersarz pewnej odmiany intelektualizmu, tematyzuje Ziemkiewicz mimowolnie etos inteligencki, wobec którego - co szczególnie interesujące - wykazuje pospołu ironiczny dystans i przywiązanie neofity5. Okoliczności pierwsza i druga zbiegają się w znacznym stopniu i można je sprowadzić zasadniczo do kwestii socjotechnicznych: ustalenia, czym jest „mowa nienawiści”, tak w swojej funkcji praktycznej (jako narzędzie sporu politycznego), jak w wymiarze językowej figuratywności (jako przestrzeń określonego typu obrazowania), ponadto określenia przystawalności diagnozy społecznej Ziemkiewicza do kryterialności naukowej. Uwzględnienie okoliczności trzeciej otwiera możliwość szerszą: spojrzenia na casus Ziemkiewicza-publicysty przez pryzmat typologii postaw inteligenckich, ich kontynuacji bądź dyskontynuacji w stosunku do postaw ukształtowanych przez tradycję, schematyczności wreszcie komunikacyjnej ${ }^{6}$ etc. W tym zaś kontekście - możliwość oceny jego spójności, rzetelności, sensowności, słowem tego wszystkiego, co w odniesieniu do wypowiedzi publicystycznej składa się na jej wiarygodność i czyni danego publicystę cennym diagnostą społecznym tudzież liczącym się uczestnikiem debaty publicznej, bądź też dyskwalifikuje go w tych rolach. Ten właśnie plan obserwacyjny uważam za najdonioślejszy i z niego wywodzić się będą najważniejsze dla rozważań podjętych nad publicystyką Ziemkiewicza wnioski. Kluczowe pytania, jakie się w związku z tym nastręczają, można by sformułować następująco: czy Ziemkiewicza postkolonialna wizja Polski współczesnej jest przekonująca i co, ewentualnie, stanowi jej differentia specifica? Jak sytuuje się Ziemkiewicz na tle polskiego dyskursu inteligenckiego i czy w jego własnej twórczości publicystycznej istnieją - ceteris paribus - przesłanki tłumaczące jej - z jednej strony - generalnie niekorzystny odbiór ze strony środowisk nieprawicowych ${ }^{7}$,

${ }^{5}$ Określenie „neofita" jest o tyle właściwe, że sam Ziemkiewicz niejednokrotnie zaznacza swoją przynależność do inteligencji w drugim pokoleniu. W "Myślach nowoczesnego endeka”, na przykład, pisze o tym następująco: „Nie ukrywałem nigdy, że w studiach nad polskim chamem posługuję się w znacznym stopniu materiałem najbardziej mi dostępnym, to znaczy sobą samym. Zbiorowe wady najlepiej obserwować na swoim przykładzie i najlepiej na sobie samym uczyć się ich przezwyciężania. Jestem inteligentem $\mathrm{w}$ drugim pokoleniu, jak prawie wszyscy współcześni Polacy wywodzącym się z deptanego przez pokolenia chłopstwa. Od większości pyskaczy zaludniających media różni mnie może tylko to, że świadomość, skąd mi nogi wyrastają, nie wprawia mnie w żadne kompleksy" (Ziemkiewicz, 2012a: 267).

${ }^{6}$ Pod pojęciem schematyczności komunikacyjnej rozumiem $\mathrm{w}$ danym przypadku model komunikacji Romana Jacobsona zastosowany do historycznej i społecznej sytuacji autora realizującego pewien typ strategii ideologicznej. $W$ tradycji o wyróżnionej roli inteligencji, takim jak Polska, w modelu tym realizowane są pewne unikalne formy relacji społecznej: inteligent $\mathrm{w}$ roli nauczyciela, a "lud" $\mathrm{w}$ roli ucznia, kod wykorzystujący określone elementy mitologii bohaterskiej, treść komunikatu skupiona na problematyce ideowej i moralnej etc.

7 Pisząc o generalnie niekorzystnym odbiorze mam nie myśli nie tylko i nie przede wszystkim odmienność rzeczowo wyartykułowanych zapatrywań, w kwestiach takich, na przykład, jak ocena 
z drugiej zaś - częściowo aprobatywny, a częściowo entuzjastyczny doń stosunek środowisk prawicowych? Idąc zaś konsekwentnie dalej: czy bycie przedmiotem tak różnych recepcji, a jednocześnie podmiotem ich krytycznej tematyzacji, wnosi - niejako mimowolnie - jakąś wartość dodaną do obrazu postkolonialnej kondycji Polaków? Wartość nie będącą własnością żadnego ze stronnictw, lecz nadpisującą się, na sposób Heglowskiej syntezy, na dyskursywnym tychże stronnictw konflikcie.

\section{II}

Nieprzypadkowo poświęciłem uwagę usytuowaniu Ziemkiewicza na rodzimym agonie polityczno-ideowym. Uważam bowiem, że warto zrewidować niektóre potoczne jego identyfikacje, $\mathrm{z}$ racji już to uproszczonego ich charakteru, już to małodusznych ograniczeń, jakie nakładają na społeczną mobilność idei tego wybitnego skądinąd publicysty. Ograniczę się tutaj do kwestii „prawicowości” Ziemkiewicza, niepotrzebnie go stygmatyzującej, a przez to w sposób szczególny zniekształcającej recepcję jego myśli. Sam zainteresowany zżyma się na tę etykietę, zauważając, słusznie zresztą, że jego oponenci po fachu, tacy jak na przykład Janina Paradowska czy Jacek Żakowski, szczęśliwie dla siebie uniknęli zaszufladkowania, jako publicyści „lewicowi”. Niesprawiedliwość tej asymetrii pogłębia fakt, że Ziemkiewicz $\mathrm{w}$ swoich wypowiedziach publicystycznych dystansuje się od poczynań partii uchodzących $w$ polskim uzusie politycznym za prawicowe, nie ukrywając wszelako pewnej, choć zawsze warunkowej, względem nich życzliwości. W "Czasie wrzeszczących staruszków”, powstałym tuż po dwuleciu rządów PiS, dokonuje fundamentalnej (do samych historycznych korzeni zjawiska sięgającej) i krytycznej (niestroniącej od dezawuowania najbardziej drażliwych dla ludzi prawicy wątków) dekonstrukcji kariery Jarosława Kaczyńskiego. Na rządy PiS-u i koalicjantów patrzy przez pryzmat racji wyższych, kompromitowanych przez fatalną politykę kadrową, fiksację na zadaniach nieadekwatnych do rzeczywistości, błędy taktyczne i wizerunkowe (czego wszak, w odróżnieniu od oponentów, Ziemkiewicz nie demonizuje), które zniweczyły w efekcie szanse na realną i szybką modernizację Polski. Nadto, przy różnych okazjach nie tai swojej niechęci do środowiska radiomaryjnego, które jawi mu się - przy całym swoim godnym uznania przywiązaniu do tradycji patriotycznych - przede wszystkim jako rezerwuar postaw roszczeniowych i antymodernizacyjnych. Wreszcie rzecz bodaj czy nie najbardziej odbiegająca od stereotypowego wizerunku polskiego prawicowca:

działalności określonego polityka, ugrupowania etc., ale krytykę bądź negację zgoła, motywowaną względami ogólniejszymi, światopoglądowymi, kamuflowanymi wszelako pozorami obiektywności i rzeczowości. 
wielostronnie negatywny stosunek Ziemkiewicza do tradycji powstańczej i romantycznej tudzież głęboko rewizjonistyczny stosunek do generalnie pozytywnego w kręgach prawicy III RP obrazu II RP (Ziemkiewicz 2014b).

Daleko bardziej pasuje do Ziemkiewicza określenie (akceptowane zresztą przezeń otwarcie) konserwatysty (w odniesieniu do sfery społecznej) i liberała (w odniesieniu do sfery gospodarczej), która to zbitka rezonuje z jego niegdysiejszymi aspiracjami politycznymi (członkostwo w Unii Polityki Realnej, zarzucone dość rychło), głęboko zżytego z ideami wolnego rynku, modernizacji kraju, sanacji państwa, republikanizmu, a w ostatnich latach - z ideałami organicznikowskimi (absorbowanymi, co prawda, za pośrednictwem spuścizny endeckiej). Właśnie z powodu owego konserwatywnego liberalizmu, o rozległej przestrzeni ideowych odniesień, trudno byłoby Ziemkiewicza pomieścić w opłotkach poszczególnych stronnictw czy partii. Łatwiej uchwycić jego profil ideowy w sporach toczonych na płaszczyźnie racji ogólniejszych. Tak jest zwłaszcza w przypadku oceny Okrągłego Stołu, Adama Michnika i całego środowiska „Gazety Wyborczej”: układ okrągłostołowy, Michnikowszczyzna i Salon to bodaj najczęstsze u Ziemkiewicza projekcje ideologicznego przeciwnika. Istnieje wszelako wymiar moim zdaniem pełniej charakteryzujący Ziemkiewiczowski światopogląd, acz łatwy do przeoczenia $\mathrm{w}$ ferworze bieżących polemik. Otóż biorąc pod uwagę charakter, przedmiot i zasięg Ziemkiewiczowskich odniesien, krytyk, interwencji, odnieść można wrażenie, że jest nasz bohater ponad wszystko wyznawcą zdrowego rozsądku przeciw ideologii, tradycyjnej moralności przeciwko obyczajowemu nowinkarstwu, ducha wspólnotowego przeciwko rozpasanemu indywidualizmowi, cierpliwego, metodycznego działania przeciwko romantycznemu woluntaryzmowi, a w ostatecznym rozrachunku: szermierzem krucjaty antyoświeceniowej z pozycji umiarkowanie konserwatywnych ${ }^{8}$. Jak powiada on sam, modelując swojego rzeczywistego wroga:

Problem w tym, że moim wrogiem, jako publicysty, nie jest jakiś konkretny spisek usiłujących zdobyć władzę nad światem (choć sam żałuję, ze świat nie jest taki uporządkowany jak w Jamesie Bondzie), ale setki osób niepowiązanych ze sobą organizacyjnie, nieznających się nawet, a mimo to robiących rzeczy podobnie głupie, podobnie szko-

${ }^{8}$ Dostrzegam wiele zbieżności między klasyczną myślą konserwatywną a poglądami Ziemkiewicza na szereg kwestii społecznych, takich jak praca, rola państwa, własność. Wystarczy przywołać takie choćby opinie Edmunda Burke'a, jednego z antenatów nowożytnego konserwatyzmu: „Skoro polityczne działania mają służyć społecznym celom, muszą być urzeczywistniane wyłącznie za pomocą społecznych środków. Tutaj umysł musi sprzymierzać się z umysłem. Czas jest konieczny dla stworzenia tego przymierza umysłów, stanowiącego jedyne źródło wszelkiego dobra, do jakiego zmierzamy. Cierpliwością osiągniemy więcej niż siłą” (Burke 248). „Władza musi być otoczona szacunkiem, a prawa muszą mieć autorytet. Nie należy na siłę wykorzeniać z ludzkich umysłów zasad naturalnego podporządkowania. Ludzie muszą respektować własność, która do nich nie należy. Muszą pracować, by zyskać to, co można wypracować [...]" (Burke 326). 
dliwe i zbiegające się w jeden wspólny wysiłek „ruszania z posad bryły świata”. Ludzi zarażonych różnymi formami tej samej ideologii, która swoje korzenie miała w naiwności oświecenia, a erupcję zbrodniczej kreatywności w marksizmie. I która skaziła cywilizacje Zachodu jak wirusy grypy, w tysięcznych mutacjach, z których każda daje nieodmiennie szkodliwe skutki (Ziemkiewicz 2011: 13-14).

\section{III}

Jeśli polityczne zaszeregowanie Ziemkiewicza jest po części skutkiem jego niedoczytania, po części dezynwoltury bądź złej woli oponentów, po części wreszcie niefortunnego zbiegu okoliczności (na razie pomijam kwestię postawioną wcześniej, czy coś obiektywnie istotnego z takiego stanu rzeczy wynika), to za swoją diagnozę polskiej rzeczywistości odpowiada on już w pełni samodzielnie. Ta zaś wydaje się w niemałej mierze tłumaczyć osobliwość jego publicznego statusu: autora zarazem ignorowanego, jak i otoczonego swoistym kultem. Zwolennika modernizacji Polski, miłego środowisku liberałów i niepoprawnego konserwatysty, odpychającego dla elit tak zwanego głównego nurtu.

Kluczowe dla zrozumienia stanowiska Ziemkiewicza-diagnosty jest jego przekonanie o istnieniu głębokiego i brzemiennego w rozliczne negatywne następstwa podziału Polaków na - jak to autor "Polactwa” różnie przy różnych okazjach nazywa - Kreoli i Tubylców, na Elitę i Kontrelitę, na Polactwo i Michnikowszczyznę, czy Familię i Konfederację etc. Z kolei podstawowym dla tego podziału układem historycznego odniesienia jest dla Ziemkiewicza folwark szlachecki. To on bowiem ukształtował główne w nowożytnej historii Polski figury społecznej interakcji i - niekiedy - mentalnej deprawacji: chłopa pańszczyźnianego (protoplasty współczesnego tak zwanego "zwykłego Polaka”, w tym peerelowskiego inteligenta), ekonoma (protoplasty polskiego inteligenta dawnego, przedwojennego, typu) i dziedzica (którego figura symbolizuje $\mathrm{z}$ kolei kolonizatora $\mathrm{w}$ jego rożnych historycznych wcieleniach: zaborczym, nazistowskim, sowieckim, nomenklaturowym, unijnym). Cezura wojenna i powojenny terror stalinowski, sprawiły, że w naturalnej dotąd ewolucji społecznej nastąpiła zasadnicza i nieodwracalna zmiana. Zanikła, wskutek fizycznego unicestwienia, ekspropriacji, prześladowań i emigracji, warstwa wypełniająca przestrzeń między chłopem a dziedzicem: inteligencja, przedsiębiorcy, mieszczaństwo przedwojenne. Dzieje narodu naznaczyła fundamentalna nieciągłość 9 . Nie jest Ziemkiewicz, rzecz jasna, pierwszym ani jedynym

${ }^{9} \mathrm{O}$ Polsce zerwanej ciągłości pisze interesująco i w znacznej zbieżności z poglądami Ziemkiewicza, Ryszard Legutko w Eseju o duszy polskiej. Czytamy tam, między innymi, że Polska powojenna „powstała jako twór nowy, budowany świadomie w opozycji do wszystkiego, czym była przez wieki. Jej nowość nie wyłoniła się stopniowo w procesie skomplikowanych wielonurtowych zmian dziejowych, przekształcających struktury społeczne, obyczaje, instytucje oraz ludzkie umysły. Nowa jest 
piewcą polskiego katastrofizmu dziejowego. Należy jednak do nielicznych, którzy nieciągłość pojmują tak radykalnie, w kategoriach zupełnego zerwania z przeszłością ${ }^{10}$. Dualna stratyfikacja, na nową, oderwaną od korzeni, elitę i pogardzany przez nią (nierzadko ze wzajemnością) ogól, wyłania społeczeństwo zupełnie odmienne od wcześniejszego, przedwojennego, jakkolwiek, podobnie jak tamto, obciążone fatalnym dziedzictwem mentalności folwarcznej. Nową jakość stanowi niewątpliwie brak tradycyjnych residuów patriotyzmu, zanik myślenia pro publico bono, zerwanie organicznej dotąd ciągłości instytucji, obyczajów i praw ${ }^{11}$. Niekorzystny wcześniej podział na chłopa, ekonoma i pana, przeszedł w podział jeszcze mniej korzystny - na chłopa i pana, których wzajemnej nieufności, niechęci i niezrozumienia nie łagodzi dobroczynny wpływ dawnej, w toku wielowiekowej, „naturalnej" ewolucji wyodrębnionej, inteligencji12.

sama istota współczesnej Polski, tak jakby wykreowano ją z nowego zarodka, nieznanego w poprzednich pokoleniach i w przeszłych wiekach. Dramatyczne zerwanie zaczął wybuch II wojny, dopełniło go zaś wprowadzenie komunizmu. Od tego momentu obcujemy ze społeczeństwem, jakiego poprzednio nie znaliśmy. [...] Wydarzenia wcześniejsze straciły wpływ nie dlatego, ze miały miejsce dawniej, lecz że dokonały się w świecie, którego już nie ma i który przestał być dla nas czytelny." Zauważa przy tym Legutko, że „doświadczenie braku ciągłości nie zostało dotąd opisane ani szerzej zidentyfikowane" (Legutko 2012b: 5-6).

${ }^{10}$ Wypowiadając się na temat genezy Polsku Ludowej, Ziemkiewicz przywołuje przy różnych okazjach na poglądy Nikodema Bończy-Tomaszewskiego. Badacz ten, podobnie jak Ziemkiewicz, podkreśla nieciągłość ewolucji społeczeństwa polskiego $\mathrm{w}$ związku z apokalipsą wojenną i budową państwa komunistycznego. Uważa on, „że dwie sprzeczne siły, Kościół i partia, niezależnie podjęły skuteczne działania nacjonalizacyjne, których efektem było powstanie nowoczesnego narodu Polskiego. $\mathrm{W}$ rezultacie $\mathrm{z}$ tego starcia narodziło się nowoczesne polskie społeczeństwo narodowe, ludowe w formie i inteligenckie w treści" (Bończa-Tomaszewski 32-33).

${ }^{11}$ Sam Ziemkiewicz zajmuje w odniesieniu do tej kwestii stanowisko pryncypialne: „Jedno z najgłupszych zdań, powtarzanych w naszych mediach, to słowa Jerzego Giedroycia, że "Polską wciąż rządzą trumny Piłsudskiego i Dmowskiego". Nigdy te słowa nie były prawdą - Giedroyć wypowiedział je będąc już na emigracji, a ówczesna emigracja, kto bliżej zna, ten potwierdzi, mentalnie pozostawała w owych czasach jakby zatrzymaną w czasie resztką Polski międzywojennej. Tymczasem tu, w kraju, trwała peerelowska "pierekowka dusz” i rodził się naród, jak celnie zauważył Nikodem Bończa-Tomaszewski, zupełnie nowy, mający za ojców - założycieli Władysława Gomułkę i Stefana kardynała Wyszyńskiego. Ten naród z Piłsudskim i Dmowskim łączyło niewiele więcej, niż z Bolesławem Chrobrym, i tak mu pozostało do dziś, gdy cytowane słowa mają jeszcze mniej sensu, niż kiedykolwiek" (Ziemkiewicz 2014c: Web).

12 Nowy inteligent, z peerelowskiego nadania, nie jest wrośnięty w tkankę życia narodowego, jak ten wcześniejszy, „naturalny”. Choć wywodzi się bezpośrednio z ludu, czyni wiele, by swoje ludowe korzenie unieważnić. Jednocześnie uniform inteligenckości ciąży mu na różne sposoby: nie jest to przecież forma, którą zinternalizował spontanicznie. Inteligent peerelowski jawi się zatem jako postać tragikomicznie niedopasowana do nowej rzeczywistości. Rozdarta między tradycją, która jest dla niej obca i niezrozumiała a nowoczesnością, która stanowi dla niej sztuczny w istocie i przytłaczający świat. Ciekawe uwagi na temat powojennej modernizacji wypowiada wspomniany już BończaTomaszewski. W jednej z nich nawiązuje do filmu „Rejs”, uważanego przez niektórych za metaforę, 
Najbardziej formotwórczą i zarazem najtrwalszą kategorią społeczną Ziemkiewiczowskiej taksonomii okazał się, z racji swojej liczebności i względnej odporności na dziejowe kataklizmy, chłop pańszczyźniany. „To z niego właśnie - powiada Ziemkiewicz - czy raczej z tej jego formy, w jakiej przetrwał dziejowy kataklizm, wyhodowała komuna podstawowy model obywatela peerelu, przejęty potem z dobrodziejstwami inwentarza przez Solidarność i III RP" (Ziemkiewicz 2012b: 137). W systemie wartości i praktyk tegoż chłopa widzi Ziemkiewicz zalążek siedmiu grzechów głównych dzisiejszego polactwa (kontrowersyjne to przez swoje słowotwórcze analogie, na przykład do "robactwa”, określenie umocniło zarzut kultywowania przez Ziemkiewicza „mowy nienawiści”13. Są to: 1. nieuczciwość, 2. nieufność, 3. zawiść, 4. lenistwo, 5. kult nieudacznictwa, 6. niezdolność współdziałania, 7. zmuzułmanienie (oznaczającego tutaj, przez porównanie do hitlerowskich obozów zagłady, atrofię woli działania, brak aspiracji życiowych). Co istotne, wedle pańszczyźnianego wzorca został ukształtowany nie tylko współczesny przeciętny Polak jako taki, ale zarazem Polak będący kanwą nowoczesnego typu obywatelstwa.

Obywatel polski - czytamy w „Myślach nowoczesnego endeka” - choć ma możność głosowania w wyborach, widzi w swoim państwie nie wspólne dobro, ale wrogi sobie, wyzyskujący go folwark, myśli tylko o tym, żeby nie dać się wykorzystać i jak najwięcej osobistych korzyści wyciągnąć, imponuje mu cwaniactwo i sam stara się być możliwie cwany. To właśnie mam na myśli, używając określenia „polactwo” (Ziemkiewicz 2012a: 144).

w dodatku wyjątkowo celną, Polski Ludowej: „Żeby poznać efekty modernizacji społeczeństwa wiejskiego, wystarczy obejrzeć „Rejs” Piwowskiego. Cały komizm tego filmu wynika ze zderzenia ludowej swojskości z nowym porządkiem, którzy przejawia się w wszystkich dziedzinach życia. Bohaterowie Rejsu śmiesznie bełkoczą nowomowa, bo próbują się poddać rygorom polszczyzny literackiej. Prowadzą absurdalne konwersacje, bo poruszają się w obcej sobie przestrzeni mieszczańskich manier i rozrywek. W czasie kuriozalnych zebrań z lękiem poddają się nowym rytuałom biurokracji. Chłoną abstrakcyjną wiedzę, którą wyrzucają z siebie w czasie absurdalnych konkursów. Pasażerowie statku za wszelką cenę usiłują stłumić i ukryć swoje niedostosowanie. Zagubieni podporządkują się nakazom władzy uosobionej przez słynnego kaowca, bo instynktownie czują, że to władza pomoże im żyć w nowym świecie. Dla widzów w latach 70. Rejs był ponurą tragikomedią o współczesności" (Bończa-Tomaszewski 17).

13 „Swego czasu musiałem ze strony publicystów i działaczy prawicy znosić wiele bardzo nieprzyjemnych uwag z powodu nazwania jej polactwem. Nie o nazwę przecież chodzi. W dawnej endeckiej publicystyce funkcjonowało rozróżnienie pomiędzy "narodem” a „żywiołem”. "Żywioł” to było jakby o oczko mniej niż naród - wspólnota języka i kultury, która nie zdołała stworzyć wspólnoty politycznej. W tym sensie pisało się o żywiole ukraińskim lub białoruskim na polskich kresach. Otóż Polactwo to nic innego jak właśnie żywioł polski, wciąż opierający się prymitywnym próbom przerobienia go na pozbawionych głębszej tożsamości wasser-europejczyków, ale oderwany także od polskiej tradycji i korzeni. Żywioł, którego tak zwane prawicowe elity przez ostatnie dwadzieścia lat nie zdołały uczynić narodem" (Ziemkiewicz 2012a: 156). 
W świetle całości Ziemkiewiczowskiej diagnozy szczególnie złowrogiego znaczenia nabiera, wymieniona jako grzech szósty, niezdolność do współdziałania. To, co u zarania zachodniej nowoczesności występowało pod postacią racjonalizacji pracy, ducha stowarzyszeń, uobywatelniania chłopa i proletariusza, w polskich realiach historycznych sprowadza się do swoistej gry pozorów, w ramach której praca stanowi nieznośny i na różne sposoby unikany ciężar, a wspólnota jest silnie zhierarchizowaną i nacechowaną wieloaspektową brutalnością dżunglą.

Dla fornala przymuszonego do pracy na cudzym folwarku nie istnieje $\mathrm{w}$ ogóle problem, czy folwark ten prosperuje, czy podupada. To sprawa dziedzica. Życie pańszczyźnianego sprowadza się do swoistej gry, jaką prowadzi z dziedzicem, gry, która ma mu zapewnić maksymalne korzyści przy minimalnych stratach. $\mathrm{Z}$ jednej strony - wywinąć się od pracy, usunąć z oczu ekonoma, ukraść, co tylko można, z drugiej - wykorzystać, na ile się da, dziedzica, wyegzekwować od niego swoje niewolnicze prawo do bezpiecznej klatki i regularnej karmy. W życiu niewolnika najbardziej się opłaca i najbardziej pożądane jest cwaniactwo (Ziemkiewicz 2012a: 143).

Ten specyficzny, narodowy darwinizm, skutkuje rozpowszechnionym w PRL-u dwójmyśleniem, nieodpowiedzialnością moralną i intelektualną, której głębszym przejawem pozostaje do dziś - na co w swoim czasie zwrócił uwagę Leszek Kołakowski - zatrata umiejętności myślenia przyczynowo-skutkowego w odniesieniu do zjawisk społecznych.

U nas tak już jest - pisze Ziemkiewicz w „Polactwie” - że cokolwiek się dzieje, winni są zawsze Oni. Inni. Obcy. Nie swoi. Winni są głupi i nieuczciwi politycy, ale w żadnym wypadku nie ci, którym wystarczy obiecać mieszkania na wiosnę, żeby na takich właśnie głosowali. Polskę okradają wielcy aferzyści, ale w żadnym wypadku nie drobni kombinatorzy wyłudzający masowo zasiłki, renty i zwolnienia lekarskie. Wtrącają ją $\mathrm{w}$ nędzę doktrynalni liberałowie, którzy nie pozwalają dodrukować tak bardzo potrzebnych pieniędzy, ale na pewno przecież nie szkodzi Ojczyźnie prywata i egoizm prostych roboli, dla których Polska istnieje tylko po to, żeby dopłacać do ich psu na buty potrzebnych miejsc pracy, choćby miało ją to doprowadzić do ostatecznego upadku i bankructwa (Ziemkiewicz 2012b: 30).

W odróżnieniu od niższych warstw społecznych, zaprzątniętych własnym interesem i programowo nieufnym względem spraw poza ów interes wykraczającym, polskie elity kolonialne, Ziemkiewiczowskich ekonomów na folwarku, charakteryzuje właściwa tej grupie od zarania orientacja na sprawy ogólne. W wydaniu powojennym znajduje ona jednak dość paradoksalny wyraz. Tradycyjnemu bowiem poczuciu misji cywilizacyjnej towarzyszy tutaj sprzeczne z nim na pozór poczucie wyższości. Nowość tej sytuacji wynika zdaniem Ziemkiewicza stąd, że dawne elity, wywodzące się na ogół z ziemiaństwa, miały względem ludu naturalne niejako uczucie zobowiązania, natomiast w elitach nowych, takiego poczucia 
wyzbytych, lud - wiecznie jakby niedorosły do wyzwań nowoczesności, niepodatny na inteligenckie projekty, nieufny i ogólnie „zaściankowy” - wywołuje przeważnie gniewną irytację. Elita Polski powojennej czuje się „bytem pośrednim pomiędzy cywilizacją, uosabianą przez metropolię i jej przedstawicieli, a miejscowymi dzikusami". Tę osobliwą mieszaninę pogardy i altruizmu nazywa Ziemkiewicz „syndromem kolonialnego sierżanta”, bo, jak powiada, „nikt bardziej nie gardzi „czarnuchem” niż jego pobratymiec, który dosłużył się u białych podoficerskiego stopnia" (Ziemkiewicz 2012a: 144). Ów ogólnie zarysowany schemat kształtowania się polskich elit, najdobitniej ujawnia się w zjawisku nazwanym przez Ziemkiewicza michnikowszczyzną. Michnikowszczyzna to

swoista próba „ochrzczenia” elity przejętej po PRL, owej nomenklatury, nowej klasy, która w czerwcu 1989 roku wypowiedziała lojalność socjalizmowi i PZPR, przez grupę działaczy opozycyjnych, cieszących się wysoką pozycją przy Wałęsie. Grupa ta, skupiona wokół Bronisława Geremka, Jacka Kuronia i Adama Michnika, nieliczna, ale obdarzona ogromnym prestiżem, zaoferowała elitom PRL całkowitą amnestię i podzielenie się prestiżem pod warunkiem uznania jej kierowniczej roli i uznania dla nowej metropolii. Zmieniając się z elity kolonialnej PRL w elitę postkolonialnej III RP, nowa klasa zastąpiła w swym systemie pojęciowym „konieczność dziejową” budowania socjalizmu „koniecznością dziejową" budowania kapitalizmu, wartości symbolizowane przez Ojczyznę Proletariatu wartościami symbolizowanymi przez Zjednoczoną Europę, a autorytety partyjne autorytetami legitymizowanymi dawną działalnością $\mathrm{w}$ „opozycji demokratycznej". Natomiast zasadniczy schemat myślenia - postrzeganie siebie jako pasa transmisyjnego pomiędzy cywilizacją a "dzikim krajem” - pozostał zgodny z nawykami myślenia ukształtowanymi w PRL. Co za tym idzie - niezmienione pozostało także myślenie o państwie, o swojej w nim roli i o tym, jakie zachowania są godziwe, a jakie nie (Ziemkiewicz 2012a: 144).

Istnieje jednak obszar zbiorowej świadomości, w którym obie odmiany ignorancji, ludowa i inteligencka, $\mathrm{w}$ przedziwny sposób się łączą. Jest to, warto zaznaczyć, obszar koniunkcji pozornej i paradoksalnej. Chodzi o mitologię bohaterską, którą polactwo - pod wpływem peerelowskiej propagandy - przyswoiło sobie prawem kaduka jako własną, a którą inteligencja peerelowska przejęła równie bezprawnie od swojej poprzedniczki. Zrodziło to szereg sprzeczności między pozorem a rzeczywistością, tak charakterystycznych dla Ziemkiewiczowskiego obrazu polskiej kolonialności. Sprzeczności te dają o sobie znać zwłaszcza w okresach przesileń, gdy z jednej strony rośnie zapotrzebowanie na postawy heroicznoofiarnicze, a z drugiej strach przed nimi. I jednocześnie tłumaczą niewytłumaczalne na pierwszy rzut oka przypływy i odpływy narodowej energii. Wymownej ilustracji dostarczają $\mathrm{w}$ tej mierze stan wojenny oraz początek transformacji ustrojowej po upadku komunizmu. Pisząc o tym pierwszym zauważa Ziemkiewicz kąśliwie, że 
i Ruskie, i ekipa Jaruzela mieli wciąż przed oczami Polaków z Armii Krajowej, z Wolności i Niezawisłości i Narodowych Sił Zbrojnych, spodziewali się barykad i wieszania zdrajców - gdy tymczasem mieli do czynienia $\mathrm{z}$ toczonym peerelowską degeneracją polactwem, do tamtych Polaków z heroicznych czasów podobnym mniej więcej w tym samym stopniu, co dzisiejszy grecki handlarz starzyzną do Leonidasa. Polactwem, które zamiast czołgami wystarczyło postraszyć zimnymi kaloryferami (Ziemkiewicz 2012c: 100).

Polski heroizm jest dziś przeto symulakrem. Czy był nim również w przeszłości? Wolno sądzić że tak, choć o innego rodzaju symulakrowość wówczas chodziło. Istotne jest tutaj wygrywanie, w związku z określonym zapotrzebowaniem społecznym, opozycji prawda-fałsz (pozór). Jeśli prawda jest po naszej stronie, a prawda jest jedna i fałsz zwycięża, celem naszym powinno być dochowanie wierności prawdzie. Tłumaczyłoby to gotowość do walki za wszelką cenę, zaciekłość i totalność sporu ideowego, nieliczenie się z przyziemnymi realiami oraz wiele innych osobliwości polskiej postawy. Ciekawego materiału obserwacyjnego dostarcza w tym względzie postawa Polaków wobec zagrożenia wojennego, analizowana przez Ziemkiewicz szeroko i wnikliwie w książce Jakie piękne samobójstwo. Polska jako uczestnik rozgrywki międzynarodowej lat 1938-39 mający bardzo dużo do stracenia, decyduje się jako pierwsza i zarazem jedyna spośród nowych krajów ładu powersalskiego przeciwstawić nazistowskiej potędze. W dodatku motywuje to - ustami ministra spraw zagranicznych - względami honoru, który tak dla jej sojuszników, jak wrogów, kalkulujących zgodnie z odwiecznymi regułami realpolitik, stanowi czynnik niepotrzebnie dezorientujący. Jak to możliwe, zapytuje Ziemkiewicz, że Polska do marca 1939 r., to jest do czasu sławetnego wystąpienia ministra Becka, postrzegana przez świat jako faktyczna sojuszniczka Hitlera (co z punktu widzenia ówczesnego układu sił i całej logiki geopolitycznej nie budzi niczyjego, włącznie z naszymi zachodnimi sprzymierzeńcami, zdziwienia), ni stąd ni zowąd wymierza temu ostatniemu policzek, stawiając się tym samym w sytuacji fatalnej, a w obliczu słabości zachodnich aliantów, nieodwołalnie samobójczej. Abstrahując od odpowiedzi sytuacyjno-politycznej (uwikłanie Becka $\mathrm{w}$ rozgrywkę z opozycją krajową), możemy widzieć w tym również przejaw owego, podnoszonego przez Ewę Thompson, platońsko-tomistycznego nieliczenia się z rzeczywistościąi14.

14 „W sarmatyzmie ujawnia się arystotelesowsko-tomistyczne pojmowanie rzeczywistości, zgodnie z którym powszechnie wiadomo, czym jest dobro, a czym zło, czym jest sprawiedliwość, a czym niesprawiedliwość itd. W Polsce, w polskim życiu intelektualnym (i niestety także politycznym), często widać taką wzruszająco naiwną wiarę. Polacy wierzą, że jeżeli pokaże się światu zakulisowe podstępne machinacje, to cały świat oburzy się i zawoła: „Skandal!”. Oczywiście tak nie będzie. To nie wszystko - w sarmatyzmie w centrum uwagi stawia się ludzką osobę. Ważny jest człowiek, a nie państwo, podbój sąsiadów czy system filozoficzny. Dlatego sarmatyzm w istotny sposób wyróżnia Polaków na tle ich sąsiadów. Stanowi zaprzeczenie rosyjskości i niemieckości". E. Thompson, Polski 


\section{IV}

Warto zauważyć, że ci, których Ziemkiewicz sytuuje po drugiej strony ideowej barykady, Salon i Michnikowszczyzna (by ograniczyć się do figur najczęściej bodaj przez Ziemkiewicza na okoliczność polemik i komentarzy przywoływanych), w postkolonialność Polski i Polaków nie zawsze skłonni są wierzyć, a przynajmniej nie zawsze skłonni są wiarę tę otwarcie wyznawać. Adam Michnik w rozmowie z Jerzym Sadeckim, na stwierdzenie możliwości zastosowania teorii postkolonialnej do badań historii PRL-u, powiada, że

ona jest bardzo ciekawa, ale ryzykowna. Dlatego, że w gruncie rzeczy odziera nasze życie w PRL-u z autentyczności. Że było to życie kolonialne i jako takie może być dziś wzięte $\mathrm{w}$ nawias. Dla teorii postkolonialnej historia Polski kończy się na „żołnierzach wyklętych" walczących po wojnie z komuną, bo wszystko, co potem, było kolonializmem. Tego bardzo się boję, bo nie ma miejsca na przykład dla kardynała Stefana Wyszyńskiego i jego polityki, a nie tylko martyrologii; nie ma miejsca dla Jerzego Turowicza, a jest dla książki Romana Graczyka o „Tygodniku Powszechnym”; nie ma miejsca dla ludzi z „Po Prostu” i Macieja Szumowskiego, który w latach 1980-1981 robił najbardziej prawdziwą i odważną "Gazetę Krakowską"; nie ma miejsca dla Leszka Kołakowskiego i Klubu Krzywego Koła, i tego wszystkiego, co było oporem literatów. Nie ma miejsca, bo to jest peryferyjny postkolonializm (Michnik et al.: 18) ${ }^{15}$.

Jeśli jednak opór Michnika, świadka czasu, przed wypaczającą intelektualizacją żywego doświadczenia, może wydawać się zrozumiały i możliwy do zaakceptowania, to inne głosy $\mathrm{w}$ sprawie, formułowane już $\mathrm{w}$ oderwaniu od kontekstu osobistego, a wśród nich zarówno te postponujące wizję Polski kolonialnej i postkolonialnej, jak i te, które każą widzieć w niej najwierniejsze zwierciadło narodowych dziejów, sądzić wypada wyłącznie na podstawie ich merytorycznej wartości. W tej zaś mierze wszelkie niezgodności poglądów między uczestnikami wojny polsko-polskiej wynikają najczęściej z różnic $\mathrm{w}$ ustaleniach z poziomu interpretacji, dotyczących określonych zdarzeń (np. stan wojenny, wstąpienie do Unii Europejskiej), postaci (Wojciech Jaruzelski, Lech Wałęsa), bądź procesów społecznych (modernizacja Polski po 1989 r.), a niekiedy po prostu z różnic w stosowanych

nacjonalizm jest niezwykle łagodny. Web. 30.05.2014. <http://wiadomosci.dziennik.pl/wydarzenia/arty kuly/206239,polski-nacjonalizm-jest-niezwykle-lagodny.html>

${ }_{15}$ Polscy intelektualiści często przeciwstawiają publiczne, oficjalne doświadczenie PRL-u, jego doświadczeniu prywatnemu. Historyk Jerzy Eisler na przykład pisze:„Tylko moją własnością są obrazy przeszłości zawierające twarze moich bliskich, przyjaciół i znajomych - niejednokrotnie już nieżyjących - wspomnienia "tamtych prywatek" i pierwszych w życiu pocałunków, wakacje na Mazurach i w Bieszczadach, radość ze zwycięstw polskich sportowców (zwłaszcza piłkarzy „złotej jedenastki” Kazimierza Górskiego), moje sukcesy, ale i - niestety - niepowodzenia. Wszystko to razem naprawdę niewiele ma wspólnego z dorobkiem i osiągnięciami Polski Ludowej. [...] Wyraźnie bowiem należy oddzielić we wszelkich próbach analiz państwo PRL od losów jego mieszkańców" (J. Eisler 49). 
strategiach retorycznych (koncyliacyjna poprawność versus wojownicze demaskatorstwo etc.). Najrzadziej mamy tu chyba do czynienia z odmową uznania użyteczności teorii postkolonialnej jako takiej. Istnieje wszakże korpus zjawisk i spraw składających się - sumarycznie - na wielką i nieusuwalną, jak się wydaje, kość niezgody. Do takich należy w pierwszym rzędzie Okrągły Stół i jego późniejsze wielorakie implikacje ideologiczne (pomijam społeczne, bo te nie należą do porządku obecnych rozważań). Jedną z nich, moim zdaniem najważniejszą, jest ocena III RP jako państwa sukcesu bądź, z drugiej strony, jako państwa "zdrady elit”. Tę pierwszą reprezentuje niewątpliwie obóz określany przez Ziemkiewicza mianem Michnikowszczyzny, tę drugą natomiast on sam. Można powiedzieć, że $\mathrm{w}$ tym punkcie bieżąca polityka miesza się z dyskursem kulturowym na tyle intensywnie, że niemożliwym staje się osiągnięcie consensusu interpretacyjnego nawet na gruncie badań akademickich. I tu również, co warto podkreślić, zdaje się uwidaczniać przywołany wcześniej syndrom platońsko-tomistyczny.

Zwolennicy teorii sukcesu podkreślają zwykle racjonalność umowy okrągłostołowej, jej historyczną celowość i zgodność z dobrze pojętym interesem narodowym, swoim przeciwnikom zarzucając nadmierną podejrzliwość, czy wręcz obsesję myślenia $\mathrm{w}$ kategoriach spiskowych. Znanym przedstawicielem tej orientacji jest Jacek Żakowski, częsty obiekt uszczypliwości Ziemkiewicza (jego określenie "Jacek „Jaś Fasola” Żakowski” uległo już bodaj środowiskowej frazeologizacji).

Nasilającej się deprywacji polityków - pisze w jednym z felietonów Żakowski - sprzyja skłonność do myślenia magicznego, które zwykłą racjonalną wiedzę o mechanizmach świata zastępuje $\mathrm{w}$ niedokształconych umysłach wiarą $\mathrm{w}$ istnienie potężnych ukrytych mocy. [...] Jak kiedyś umysły przesądne [...], tak dziś umysły cierpiące na deprywację, a posiadające predyspozycje do magicznego myślenia, otaczające nas zło, bóle transformacji, jej nieuniknione lub zawinione potknięcia oraz patologie realnie istniejące próbują przypisać ukrytym złym mocom - potężnym nieformalnym albo nielegalnym więzom (Żakowski 208).

Te dwa przeciwstawiane sobie wątki - ukrytych i możliwych do usunięcia sił oraz jawnych a nieuniknionych trudności tudzież racjonalności oraz przesądu, sukcesu oraz porażki etc. - są, moim zdaniem, niezmiernie ważne, bo przekładają się na generalną opozycję pozoru (w wersji dosadniejszej: fałszu) i prawdy, wokół której osnute zostały podstawowe narracje postkolonialne współczesnej Polski. Używanie zaś tak silnie nacechowanych moralnie oraz poznawczo kategorii (prawda-fałsz) skutkuje totalizacją sporu, jego nieuchronnym przeniesieniem z płaszczyzny bezinteresownej interpretacji na płaszczyznę światopoglądowej absolutyzacji ${ }^{16}$. Fundamentalizm, który obie strony zarzucają sobie wzajemnie, jest

${ }^{16}$ Myślę, że do niezwykle interesujących rozpoznań mogłoby doprowadzić zastosowanie rozpatrywanych tutaj gestaltów pojęciowych do analizy tych postaw współczesnych Polaków, które znaj- 
zatem immanentną cechą każdej z nich. Każdej wydaje się, że to ona stoi przynajmniej o szczebel wyżej od drugiej i widzi więcej, wszechstronniej, i wnioski ze swoich obserwacji wyciąga rozumniejsze, bardziej zgodne (czy po prostu zgodne) z rzeczywistością. Nie wdając się w szczegóły, sprowadza się to do klasycznego już schematu inteligenckiej samoświadomości: rozumiemy, my i nam podobni, o co $\mathrm{w}$ tym wszystkim naprawdę chodzi, wy zaś w najlepszym razie błądzicie, a w najgorszym przejawiacie mnóstwo złej woli, która dyskwalifikuje was w roli naszych oponentów i sprawia, że w ogóle nie powinno was być. Ktoś złośliwy mógłby skwitować sprawę odwołaniem do Marksowskiego konceptu „fałszywej świadomości": dopóki trwa walka przekonań i ukryta w naturze rzeczywistości prawda nie zatriumfowała, nosiciel każdego z przekonań ma podstawy do nadziei - złudne, nawiasem, z konieczności - że to właśnie jego punkt widzenia jest słuszny.

Myślę, że moje wcześniejsze skrupuły dotyczące wizerunku publicznego Ziemkiewicza, a także własnego względem jego publicystyki samookreślenia, znalazły niejakie usprawiedliwienie. Samemu doznając emocji po trosze obserwatora, a po trosze uczestnika konfliktu (choćby $\mathrm{z}$ racji obywatelskiego zaangażowania), z wnętrza zatem polskiego czyśćca przemawiając, swój punkt obserwacyjny trzymam na gruncie nader niepewnym. Ale zarazem stwierdzam, że inaczej być nie może. Rzecz bowiem dotyczy tożsamości, a więc kategorii warunkującej moje samopostrzeganie, jak i obraz świata, a jednocześnie płynnej i niejednoznacznej. Mamy tutaj do czynienia z aporią, podobnej do tej, jaka jest udziałem kantowskiej epistemologii, gdzie struktura przedmiotu warunkowana jest strukturą władz poznawczych. I choćby nie wiem jak bardzo się chciało z sieci tych władz wyplątać, i na przedmiot spojrzeć okiem nieuzbrojonym, nie sposób tego dokonać bez popadnięcia $\mathrm{w}$ błędne koło. Tam samo $\mathrm{w}$ przypadku rozpatrywanego tutaj polskiego syndromu: choćbyś go - parafrazując Horacego - widłami wypędzał, on zawsze powróci i, zwycięski, pokona naszą głupią pychę ${ }^{17}$. Wikłać się weń, roz-

dują się w orbicie zainteresowania teorii postkolonialnej. Legutko w swojej charakterystyce "duszy polskiej" zwraca uwagę na skłonność Polaków do skrajnych negacji i afirmacji w relacji z metropolią (Zachodem). „Polacy, aby stać się podobni do innych narodów, powinni byli zacząć od przyznania, że są od tych narodów inni, czyli gorsi. Narody cywilizowane, jak wierzono, wyzwoliły się z pokus imperialnych zbudowanych na niezdrowej pamięci o przeszłej wielkości oraz ze skłonności do bezpożytecznego rozpamiętywania klęsk. Aby stać się tacy jak inni, musieliśmy mieć świadomość własnej odrębności, która faktycznie była świadomością własnej gorszości. Pielęgnowaliśmy w sobie - rzekomo w celach terapeutycznych - poczucie lichości i marginalności. Polak wchodzący do społeczności międzynarodowych powinien zacząć od poważnej ekskuzy za swoją tak odmienną duszę, a następnie dawać cały czas do zrozumienia, że ową przeklętą różnicę dzielącą od reszty świata będzie się starał wyeliminować" (Legutko 133-134). Przywodzi to na myśl zauważoną wyżej tendencję do absolutyzacji wartości prawdy i fałszu.

$17 \mathrm{~W}$ oryginalnej, Horacjańskiej, wersji podmiotem wypowiedzi jest natura. „Naturam expelles furca/ tamen usque recurret/ et mala perrumpet furtom fastidia victrix". Horacy <http://www.frischercon sulting.com/bf3e/horaces-villa/poetry/Epistle1.10> 
trząsać nastręczane przezeń dylematy, wojować z przeciwnikiem równie niepogodzonym $\mathrm{z}$ faktem naszego istnienia, co my z jego, nie jest wcale nierozsądniej niż dystansować się doń z poczuciem intelektualnej przewagi tego, kto w spory emocjonalne, jako nierozstrzygalne, z zasady nie wchodzi. Nie jest, bo nie da się odeń uciec, bez wyrzeczenia się własnej tożsamości. Być zwłaszcza polskim inteligentem, to - nolens volens - mieć mniejszy lub większy problem z tożsamością. Jak zauważa Ziemkiewicz w Myślach nowoczesnego endeka:

Spór w Polsce nie jest [...] sporem między klasycznie pojmowaną prawicą i lewicą. Nie jest też sporem między bogatymi i biednymi (choć oczywiście władza i jej klientela mają się generalnie lepiej), między wykształconymi a niewykształconymi etc. Jest to spór o tożsamość. Dlatego właśnie generuje tak potężne emocje, przypominające wojnę domową (Ziemkiewicz 2012a: 137) ${ }^{18}$.

\section{V}

Pytanie ze wstępnej części rozważań, czy Ziemkiewicza postkolonialna diagnoza Polski współczesnej jest przekonująca, wypada zatem uznać za źle postawione. Opowiadając się bowiem za Ziemkiewiczem lub przeciwko niemu, wikłamy się $\mathrm{w}$ spór światopoglądowy $\mathrm{z}$ natury rzeczy nierozstrzygalny. A przecież wolelibyśmy zachować status niezależnych obserwatorów i przynajmniej zaczekać do czasu, w którym okaże się co dobrego i (lub) złego z tego sporu wynikło. Myślę, że całą tę konfuzję można by ująć jeszcze dosadniej: wybierając wizję kraju sukcesu lub kraju zdrady optujemy nie tyle za prawdą bądź iluzją, ile - w ostatecznym rozrachunku - za określoną projekcją zbiorowej przyszłości. Jest to deklaracja tyleż poznawcza, co moralna, choć jedynie tę drugą możemy złożyć bez popadania w tożsamościową pułapkę.

Jak zresztą mielibyśmy rozstrzygnąć tejże diagnozy prawidłowość? Z użyciem jakich kryteriów? Poprzez odwołanie do dekonstrukcyjnej tekstologii, która wykaże określonego pochodzenia cudzo-słowność Ziemkiewiczowskich narracji, a poprzez nią - nieuchronne wewnętrzne pęknięcia i sprzeczności? Do metod pomiaru socjologicznego, które operowały będą pojęciem korelacji, doboru próby, metod ilościowych i jakościowych, dające się w istocie zredukować do problemu prze-

${ }^{18}$ Genezę funkcjonującego w minionym ćwierćwieczu podziału na lewicę i prawicę widzi Ziemkiewicz następująco: „Strony politycznego konfliktu uformowały się w zależności od jednej z dwóch możliwych odpowiedzi na pytanie: co zrobić z odziedziczonymi po PRL, postkolonialnymi elitami? Tych, którzy chcieli na nie stawiać, którzy je rozgrzeszyli z dawnych win i przyznali im kierowniczą rolę w modernizowaniu państwa, przyjęło się nazywać lewicą. Tych, którzy domagali się głębokiego przekształcenia albo całkowitej wymiany, potępienia, choćby tylko symbolicznego, i stworzenia elit nowych, nazwano prawicą. Głównym przedmiotem walki pomiędzy nimi stała się zaś kwestia, komu należy się społeczny szacunek" (Ziemkiewicz 2012a: 142-143). 
kładu językowego? Owszem, wszystko to jest możliwe do przeprowadzenia, tyle tylko, że i tak ostatecznie wzięłyby górę racje nieweryfikowalne, odwołujące się do doświadczeń życiowych zainteresowanego ${ }^{19}$.

Dużo bardziej zasadne wydaje się pytanie o swoistość Ziemkiewiczowskiej diagnozy. Zwracałem już uwagę $\mathrm{w}$ tym kontekście na jej radykalność (nieciągłość tradycji), teraz wypada dołączyć jeszcze właściwość języka, nie omówioną wcześniej. Otóż jest to język ogarniający rozległe obszary żywiołu literackiego, dziennikarskiej eksperiencji i mowy żywej, przechodzącej z równą łatwością w gawędziarskie wielosłowie, co w zgrubny a oszczędny kolokwializm; język potocznego doświadczenia, zdroworozsądkowego osądu i erudycyjnej puenty; język niewolny od dosadności sformułowań, satyrycznych przerostów i deformacji, choć przy tym wyzbyty nieuzasadnionej wulgarności. Potrafi Ziemkiewicz skomplikowane zjawisko zobrazować poprzez uwypuklenie jednego, ale charakterystycznego dlań i niezmiernie sugestywnego szczegółu. Jak na przykład wówczas, gdy opisuje zmianę władzy po wyborach 2007 roku: „Czas wrzeszczących staruszków dobiegł końca. Zaczyna się czas uśmiechniętych, przymilnych i wygładzonych aż do obłości politycznych żigolaków, niestarających się nikogo wyprowadzać na barykady" (Ziemkiewicz 2008: 475). Innym razem nie stroni Ziemkiewicz od brutalnej naturalizacji, która ściąga nań, jakże niesłusznie, odium kultywatora „mowy nienawiści”: „PRL był to po prostu syf. Wielki, obrzydliwy syf. Kraj szarości i brudu, kraj łuszczącego się tynku i smrodu obsączanych bram" (Ziemkiewicz 2011: 29). Niesłusznie, bo język autora Polactwa jest tyleż wykwitem, co narzędziem jego społecznej diagnozy. Medium prawdy i narzędziem jej przywracania w rzeczywistości pełnej - w ujęciu Ziemkiewiczowskim - fałszu i pozorów. Można przystać na taki język, przy założeniu, że istnieje faktycznie odpowiadająca mu rzeczywistość. A więc popadając jednocześnie $\mathrm{w}$ tradycyjnie polską absolutyzację.

Dodatkowym wytłumaczeniem podnoszonych osobliwości formalnych może być okoliczność natury biograficznej. Ziemkiewicz, jakkolwiek do dziedzictwa kolonialnego intelektualnie zdystansowany (mało powiedziane), potrafiący finezyjnie rozpracowywać rozmaite jego zależności w meandrach bieżącej polityki i w postawie społecznej, przyznaje się jednocześnie, szczerze i bez fałszywej pretensji, do silnego w nim zakorzenienia. Wyjścia wszelako z tożsamościowej matni nie poszukuje, wzorem wielu swoich kolegów z przeciwnego obozu, w przezwyciężaniu określonego języka przeszłości, w zwalczaniu jego form nieznośnie już

${ }^{19}$ Moim zdaniem istnieje jedyny możliwy test wiarygodności Ziemkiewicza, nie rozstrzygający wszelako sprawy na gruncie ogólniejszym, dyskursywnym. Otóż, jeśli nie wiesz, drogi czytelniku, czy Ziemkiewicz ma rację, przeprowadź na sobie prosty eksperyment. Sprawdź mianowicie, czy diagnoza Polski i polskości zawarta $\mathrm{w}$ rozpatrywanych tutaj książkach, budzi w Tobie odpowiednio wyraziste emocje. Wyraziste, to znaczy nie jakiekolwiek, w rodzaju przyjemności czytelniczej, żachnięcia się na gadanie, z którego nic nie wynika etc., ale takie emocje, które sytuują cię względem lektury na pozycjach wrogich bądź sojuszniczych. Które generują, co najmniej, odruch sprzeciwu lub pomruk aprobaty. 
zleżałych, w tropieniu nieprawidłowości we wzorach dyskursywnych obrazów świata etc. Jako się rzekło, język Ziemkiewicza, szczególnie w „Polactwie”, trąci dosadnością, lecz jest to dosadność, by tak rzec, prostodusznie chwacka, zespolona z empirią. Bo Ziemkiewicza interesuje, jak na potomka chłopów pańszczyźnianych przystało, czyn, postawa, konkret, to, co w garści, a nie to, co w gębie czy na dachu. Sięga w swoim poszukiwaniu konkretu nie bardzo daleko, jak Ewa Thompson (która, przypomnijmy, chciałaby odnawiać w Polaku Sarmatę kosztem Polaka romantyka), ale też i nie bardzo blisko, do spuścizny endeckiej mianowicie z czasów jej twórczego krzepnięcia jako odłamu myśli organicznikowskiej. Programu działania wszelako Ziemkiewicz nie formułuje. Bo i, jak przyznaje z rozbrajającą szczerością, pojęcia nie ma, na czym taki program miałby dzisiaj polegać. W konkluzjach Myśli nowoczesnego endeka znajdujemy jedyną praktyczną wskazówkę, jakiej udziela w tym względzie swoim czytelnikom: „Gdybym miał sformułować i upowszechniać jakieś polityczne wezwania, upowszechniłbym jedno, następujące: „Oddaj ojczyźnie cztery godziny w tygodniu” (Ziemkiewicz 2012a: 302). Ale, dodaje zaraz, „,na co konkretnie przeznaczą Państwo te swoje cztery - albo, daj Boże, jak najwięcej - godziny, nie śmiem się w to mieszać (Ziemkiewicz 2012a: 302). Ani zatem Ziemkiewicz odtwarza, ani konserwuje tradycyjne linie polskich podziałów. To raczej jego przeciwnicy ideowi czynią zeń figurę nadającą się do użycia w tak tradycyjnie rozumianej propagandzie wojennej. $Z$ jednej strony, owszem, nadaje się Ziemkiewicz do tego, bo do jednych mu bliżej (Fronda, PiS, neokonserwatyści, liberałowie), a do drugich dalej (Krytyka Polityczna, PO, postkomuniści, lewica europejska etc.), bo raz jednych, raz drugich, bez skrupułów odziera z powagi, a siebie samego - nieodmiennie - ze złudzeń. Na tym przecież polega powinność rycerza Prawdy: wiedząc gdzie dobro, a gdzie zło, wspomagać pierwsze, a zwalczać drugie. W tym znaczeniu Ziemkiewicza koncepcja polskości lepszej (bardziej pożądanej), prawicowej w wydaniu endeckim, może jawić się jako aporetyczna, ujawniająca nieusuwalne - $\mathrm{z}$ natury rzeczy - sprzeczności stające na drodze wszelkiej maści absolutystów, tych, którzy określone słabości polskiego samoobrazu pragnęliby przezwyciężać poprzez odwołania do innych, konkurencyjnych, tego samoobrazu wariantów i wcieleń (Polska lewicowa vs. Polska prawicowa etc.). Dlatego, z drugiej strony patrząc, Ziemkiewicz jako ideolog musi zawieść wszystkich upatrujących w nim swojego przywódcy i kodyfikatora „lepszej Polski”.

Właśnie z radykalizmem ujęcia i światopoglądową wyrazistością wiąże się zauważona wcześniej nieprzezwyciężalna kontrowersyjność Ziemkiewicza (dla jednych idol, dla drugich wróg). Wiemy już, że jest to efekt stanu rzeczy ustalonego przez historię i wciąż utrwalanego przez jego tematyzację: polski dyskurs postkolonialny jest funkcją polskiego dyskursu tożsamościowego (i na odwrót). Wchodząc $\mathrm{w}$ jeden $\mathrm{z}$ nich stajemy się automatycznie uczestnikami drugiego, ze wszystkimi tego społecznymi, ideowymi i emocjonalnymi konsekwencjami. Wybór statusu badacza polskiej postkolonialności nie jest neutralnym światopoglądowo aktem 
intelektualnej inkluzywności, lecz znaczącą społecznie manifestacją określonej postawy moralnej, a w sferze praktycznej deklaracją przynależności do tak czy inaczej rozumianego projektu reformy ${ }^{20}$. Zastanówmy się jeszcze na koniec nad możliwością dostrzeżenia w tym wspomnianej na początku „wartości dodatkowej". Otóż uważam, że taka wartość istnieje. Stanowi ją ten aspekt sytuacji komentatora polskiej postkolonialności (Ziemkiewicz może stanowić tutaj jego modelowy okaz), który poważnie ogranicza, jeśli wręcz nie udaremnia, możliwość formułowania przezeń rozwiązań mających na celu rozsupłanie owej błędnej zależności: dyskurs postkolonialny - tożsamość. Tym najprawdopodobniej należy tłumaczyć widoczną u Ziemkiewicza niezdolność do konceptualizacji pozytywnego programu działania ${ }^{21}$. Konceptualizacja taka oznaczałaby partykularyzację celów, kłócącą się z dyskursem pojętym jako przestrzeń swobodnej wymiany doświadczeń, po drugie danie pierwszeństwa jednemu z wariantów postkolonialności (prawica kontra lewica etc.), co oznaczałoby zapewne nie przezwyciężenie syndromu postkolonialnego, lecz jego utrwalenie, a po trzecie zatrzymanie procesu emancypacyjnego (mam na myśli emancypację z sytuacji postkolonialnej) na etapie, na którym oznaczałoby to jego faktyczną inwolucję (na przykład na etapie ciągłego i bezcelowego z uwagi na społeczne realia „rozliczania przeszłości”). Dlatego program minimum Ziemkiewicza, jego selektywne i szkicowe, a nie programowe odniesienia do spuścizny organicznikowskiej i narodowej, jego swobodne, nieobciążone trybutem politycznym demaskacje wynaturzeń polskiego życia publicznego, wydają się pomyślną oznaką (zapowiedzią) uwalniania narodowej tożsamości z jej najgroźniejszych, bo najsilniej utrwalonych, dyskursywnych pułapek.

\section{BIBLIOGRAFIA PODMIOTOWA}

Ziemkiewicz, Rafał A. (2008) Czas wrzeszczacych staruszków. Lublin: Fabryka Słów, 2008.

Ziemkiewicz, Rafał A. (2011) Viagra mać. Lublin: Fabryka Słów 2011.

\footnotetext{
${ }^{20}$ Myślę, że podobne obserwacje można by zastosować i do innych krajów zmagających się z kolonialnym dziedzictwem. Przypuszczam jednak, że zachodzi w tym względzie zasadnicza różnica między krajami dominującymi i zależnymi: porównywalnie skomplikowane do polskich uwikłania tożsamościowe dotyczyć mogą głównie, jeśli nie wyłącznie, krajów zależnych.

${ }^{21}$ Po raz kolejny uwidacznia się tu realizm i konserwatyzm Ziemkiewicza, który rezygnując $\mathrm{z}$ wchodzenia $\mathrm{w}$ tradycyjne ideologiczne absolutyzacje, zaleca drogę stopniowej, oddolnej normalizacji, pozwalającej uniknąć niebezpieczeństw implikowanych przez dychotomię prawdy i fałszu. Za ilustrację niech posłuży następujący cytat: „Musimy sobie poradzić tak, jak to zrobili Amerykanie. Nie ufając "klasie politycznej” i w ogóle szeroko pojętym elitom, tworząc jak najliczniej i na wszystkich możliwych poziomach republikańskie siły i instytucje służące ich kontrolowaniu oraz korygowaniu ich postępowania. Polski nie zmodernizują wąskie elity, które wiedzą lepiej, czyniąc to tak jak od lat dwudziestu bezskutecznie próbują. Polskę zmodernizuje demokracja albo Polski nie będzie wcale" (Ziemkiewicz 2012a: 292-293).
} 
Ziemkiewicz, Rafał A. (2012a). Myśli nowoczesnego endeka. Lublin: Fabryka Słów 2012.

Ziemkiewicz, Rafał A. (2012b). Polactwo. Lublin: Fabryka Słów, 2012.

Ziemkiewicz, Rafał A. (2012c). Michnikowszczyzna. Zapis choroby. Lublin: Fabryka Słów, 2012.

Ziemkiewicz, Rafał A. (2014a). Jak zostatem polskim faszystą. „Do Rzeczy” 2014, nr 13.

Ziemkiewicz, Rafał A. (2014b). Jakie piękne samobójstwo. Lublin: Fabryka Słów, 2014.

Ziemkiewicz, Rafał (2014c). „Faszyści Piłsudski i Dmowski - niech żyją!” Web. 12.08.2014. <http:/ fakty. interia.pl/felietony/ziemkiewicz/news-faszysci-pilsudski-i-dmowski-niech-zyja,nId,907916>

\section{Bibliogragfia przedmiotowa}

Bończa-Tomaszewski, Nikodem. „Narodziny Polski Ludowej”. Fronda 39 (2006). S. 32-33.

Burke, Edmund. Rozważania o rewolucji we Francji. Przeł. D. Lachowska. Warszawa: Wyd. Uniw. Warszawskiego, 2008.

Eisler, Jerzy. Dziedzictwo Peerelu. W: III Rzeczpospolita w trzydziestu odsłonach. Red. A. Kostarczyk. Warszawa: Świat Książki, 2004.

Horacy, Epistles I.10. Web.30.07.2014 <http://www.frischerconsulting.com/bf3e/horaces.villa/po etry/nEpistle1.10.html>

Legutko, Ryszard (2012a). Triumf człowieka pospolitego. Poznań: Zysk i S-ka, 2012.

Legutko, Ryszard (2012b). Esej o duszy polskiej. Poznań: Ośrodek Myśli Politycznej 2012.

Michnik, Adam. „Ile dać wolności przeciwnikowi. Rozmowa a Adamem Michnikiem”. W: A. Michnik Adam et al. Kim sa Polacy. Warszawa: Agora SA, 2013.

Thompson, Ewa. „Polski nacjonalizm jest niezwykle łagodny”. Web. 30.05.2014. <http://wiadomosci. dziennik.pl/wydarzenia/artykuly/206239,polski-nacjonalizm-jest-niezwykle-lagodny.html>

Wildstein, Bronisław. Demokracja limitowana, czyli dlaczego nie lubię III RP. Poznań: Zysk i S-ka, 2014.

Żakowski, Jacek. „Kraina latających smoków”. Nauczka. Warszawa: Krytyka Polityczna, 2007. 